\title{
EPIDEMIOLOGY OF SEVERE ACUTE RESPIRATORY SYNDROME (SARS) CAUSED BY COVID-19 IN THE STATE OF BAHIA
}

\author{
D. A. FERREIRA ${ }^{1}$, W. B. DA SILVA ${ }^{2}$, A. P. DA SILVA ${ }^{3}$, M. A. ELOY ${ }^{4}$, L. V. CORDEIRO ${ }^{5}$, F. P. DE ANDRADE JR ${ }^{6}$ \\ Universidade Federal de Campina Grande ${ }^{1-4}$, Universidade Federal da Paraíba ${ }^{5,6}$ \\ ORCID ID: https://orcid.org/0000-0002-5262-6262 ${ }^{1}$ \\ E-mail: daviazevedoferreira@hotmail.com ${ }^{1}$
}

Submetido $15 / 08 / 2020$ - Aceito $x x / x x / 20 x x$

DOI: 10.15628/holos.2020.10979

\begin{abstract}
The objective of this study was to evaluate the epidemiological profile of people affected with Severe Acute Respiratory Syndrome (SARS) caused by COVID-19 in the state of Bahia, from March 7 to June 5, 2020. It is an epidemiological, retrospective and documentary study, in which data collection was performed through the "Monitora Covid-19". The variables analyzed were: week of notification, sex, age and the number of deaths. The absolute and relative frequencies were analyzed and the Chi-Square test of Independence was applied, in which $p<0.05$ was considered statistically significant. There were 26,418 cases of covid-19 in the State of Bahia,
\end{abstract}

with 1,977 of those affected developing SARS. Male individuals (54.9\%) and and above 60 years of age $(50.9 \%)$ were the most prevalent, but there was no statistically significant association between the variables $(p=0.372)$. Among the 806 deaths, there was a higher mortality in men (56.7\%), with a lethality rate of $42.1 \%$. In addition, there was a positive association for death in individuals aged 60 years or older and a positive association for absence of death between individuals aged 0 to 19 years and 20 to 59 years $(p<0.001)$. Based on what has been exposed, there is an accelerated growth in the number of people affected by COVID-19 in Bahia in the three months analyzed.

KEYWORDS: Coronavirus infections, COVID-19, SARS-CoV-2, Epidemiology, Coronavirus.

\section{EPIDEMIOLOGIA DA SÍNDROME RESPIRATÓRIA AGUDA GRAVE (SARS) CAUSADA POR COVID-19 NO ESTADO DA BAHÍA}

\section{RESUMO}

Objetivou-se avaliar o perfil epidemiológico de acometidos com Síndrome Aguda Respiratória Grave (SARS) advinda da COVID-19 no estado da Bahia, no período de 7 de Março a 5 de Junho de 2020. Trata-se de um estudo epidemiológico, retrospectivo e documental, em que a coleta de dados do "Monitora Covid-19". As variáveis analisadas foram: semana de notificação, gênero, idade e o número de óbitos. Analisou-se as frequências absoluta e relativa e o teste do Qui-Quadrado de Independência foi aplicado, em que $p<0,05$ foi considerado estatisticamente significativo. Foram evidenciados 26.418 casos da covid-19 no Estado da Bahia, sendo que 1.977 dos acometidos desenvolveram
SARS. Indivíduos do sexo masculino $(54,9 \%)$ e de idade a partir de 60 anos $(50,9 \%)$ foram os mais prevalentes, porém não foi observado associação estatisticamente significativa entre as variáveis $(p=0,372)$. Dos 806 óbitos, observou-se maior mortalidade em homens $(56,7 \%)$ com taxa de letalidade de $42,1 \%$. Além disso, evidenciou-se associação positiva para óbito em indivíduos com 60 anos ou mais e associação positiva para ausência de óbito entre indivíduos de 0 a 19 anos e 20 a 59 anos $(p<0,001)$. A partir do que foi exposto, constata-se que houve crescimento acelerado do número de acometidos pela COVID-19 na Bahia nos três meses analisados.

PALAVRAS-CHAVE: Infecções por Coronavirus, COVID-19, SARS-CoV-2, Epidemiologia, Coronavírus.

HOLOS, Ano 36, v.5, e10979, 2020 


\section{INTRODUCTION}

In In November 2002, cases of "atypical pneumonia" appeared in the city of Foshan, Guangdong, China. The infection was later spread to Hong Kong by a doctor who took care of cases similar to atypical pneumonia. As a result, there were outbreaks in Hong Kong and, on March 15, 2003, the World Health Organization (WHO) designated the cases as "severe acute respiratory syndrome" (SRAG or SARS - severe acute respiratory syndrome). WHO declared the end of the SARS outbreak on July 5, 2003, so that 8,096 cases and 774 deaths occurred in 29 nations, which corresponds to a lethality rate of 9.6\% (Hui \& Zumla, 2019; Al-qahtani, 2020).

Years after this infection, which was characterized by atypical pneumonia caused by a new type of coronavirus, a new etiological agent emerged in 2019. This agent was described as a new beta-choronavirus, which received the name SARS-Cov-2 (acute respiratory distress coronavirus syndrome). And, through investigations, it was discovered that bats and civets sold in the markets of China were, respectively, the reservoir and intermediate hosts of the virus (Costa, Moreli \& Saivish, 2020).

The SARS-Cov-2 virus has lipids and S glycoproteins on its surface. Glycoprotein S is critical to its ability to infect, directing where and how the virus will enter and attach itself to human cells. It is also responsible for binding the virus to the human cell receptor, promoting the fusion of the viral envelope with the cell. The receptor by which SARS-Cov-2 binds is a proteoglycan of heparan sulfate and can therefore be associated with ACE-2 (Angiotensin-2-converting enzyme). ACE-2 is found throughout our bodies, although it is found in greater quantities in the lungs. Because of this, one of the main symptoms is in the respiratory system, which can lead to more serious cases, generating SARS. The discovery of the proteoglycan heparan sulfate receptor is an important tool for the development of new therapeutic alternatives, such as the manipulation of heparan sulfate or inhibition of viral adhesion by exogenous heparin (Chen et al., 2020; Clausen et al., 2020).

The pathological process of SARS occurs by connecting the viral envelope to ACE-2 present in lung cells. Thereafter, the viral cycle includes evasion of the host's innate response, uncontrolled viral replication and activation of a severe adaptive immune response. The inflammatory loop is composed of an exacerbated inflammatory response that fuels the infection until it explodes in a veritable cytokine storm. The negative regulation of the ACE- 2 axis leaves the lung without a critical defense mechanism and turns the balance over to the side of uncontrolled inflammation, generating the syndrome (Domingo et al., 2020).

In 2019, in China, more specifically in the city of Wuhan, a new virus of the family Coronaviridae appeared, whose name was initially called New Coronavirus 2019-nCoV and later renamed SARS-Cov-2. This virus can cause a disease commonly called COVID-19, which can lead to serious complications, such as Severe Acute Respiratory Syndrome (SARS). In addition, in 2020, on March 11, the World Health Organization (WHO) declared the SARS-Cov-2 pandemic (Cheng \& Shan, 2020).

The SARS-Cov-2, like the other members of the family, has as genetic material a single ribonucleic acid (RNA) strand, in which it is distinguished from the others by the different 
organization of its nucleotides present in the chain, being considered a new type of virus. Morphologically, the viral particles are round or oval, having a diameter of 60 to $140 \mathrm{~nm}$ (Trindade et al., 2020).

The infection caused by the new coronavirus is highly contagious and can cause asymptomatic conditions or even more extreme situations, such as Severe Acute Respiratory Syndrome (SARS) and death (Santos et al., 2020). SARS, in turn, is defined as the worsening of an individual with an acute respiratory condition, in which, regardless of age, the person may show signs and symptoms such as: difficulty breathing, sore throat, myalgia, dyspnoea or less than oxygen saturation 95\% (Silveira et al., 2020).

The Diagnosis of SARS-Cov-2 infection is made with the collection of respiratory material (aspiration of the airways or sputum induction). Laboratory diagnosis to identify the virus is performed using quantitative reverse transcription polymerase chain reaction (RTq-PCR) techniques in real time and partial or total sequencing of the viral genome. It is recommended to collect nasopharyngeal aspirate or combined swabs (nasal / oral) or sample of lower respiratory secretion (sputum or tracheal or bronchoalveolar lavage). To confirm the disease, it is necessary to carry out molecular biology tests that detect viral RNA. Serious cases that can lead to SARS should be referred to a referral hospital for isolation and treatment. Mild cases must be accompanied by primary health care and home precautionary measures instituted (Lima, 2020).

According to data from the Pan American Health Organization (PAHO), until July 24, 2020, 15,296,926 cases of COVID-19 and 628,903 deaths were confirmed. In Brazil 2,397,174 cases were registered and 86,517 deaths confirmed by the disease (PAHO, 2020; FIOCRUZ, 2020). Given the above, it is noted that the complications of severe acute respiratory syndrome (SARS) due to the coronavirus is an emerging global health problem, which leads to the need for emergency control and prevention actions aimed at reducing the spread of the virus. It is seen that epidemiological studies are very relevant in this pandemic scenario, as they help to identify the most affected population and provide data that contribute to the creation of public policies.

The aim of this study was to elucidate the epidemiological profile of patients affected with Severe Acute Respiratory Syndrome (SARS) by COVID-19 in the state of Bahia, Brazil, from March 7 to June 5, 2020.

\section{METHODOLOGY}

\subsection{Study type}

This is an epidemiological, retrospective and documentary study, using the secondary data available in the "Monitora Covid-19", created by the Institute of Communication and Scientific and Technological Information in Health of the Oswaldo Cruz Foundation (Icict/Fiocruz), in which the infections that occurred in the State of Bahia, collected from March 7 to June 5, 2020, were evaluated.

\subsection{Study Location}


The State chosen for study was Bahia, considering that, among the Northeast States, it was the first to present confirmed cases of COVID-19.

The State of Bahia, located in the Northeast region, has an estimated population of $14,873,064$ and a territorial area of $564,760.427 \mathrm{~km}^{2}$, which has a demographic density of 24.82 inhabitants $/ \mathrm{km}^{2}$. The Human Development Index (HDI) in the Region is 0.660 and per capita household monthly income of R\$ 913.00 (IBGE, 2019).

\subsection{Analyzed Variables}

The week of notification, sex, age and number of deaths were analyzed.

\subsection{Statistical analysis}

Statistical analysis was performed using the Statistical Package for the Social Sciences (SPSS) software, version 13.0. The Independence Chi-Square test was applied and the associations were considered statistically significant, for rejection of null hypotheses, when $p<0.05$. In addition, adjusted residuals and lethality rates were calculated.

\section{RESULTS AND DISCUSSION}

Between March 7, 2020 and June 5, 2020, 26,418 cases of covid-19 were found in the state of Bahia (Figure 1), in which 1,977 affected people developed the Severe Acute Respiratory Syndrome, representing $7.48 \%$ of those infected with SARS -CoV-2.

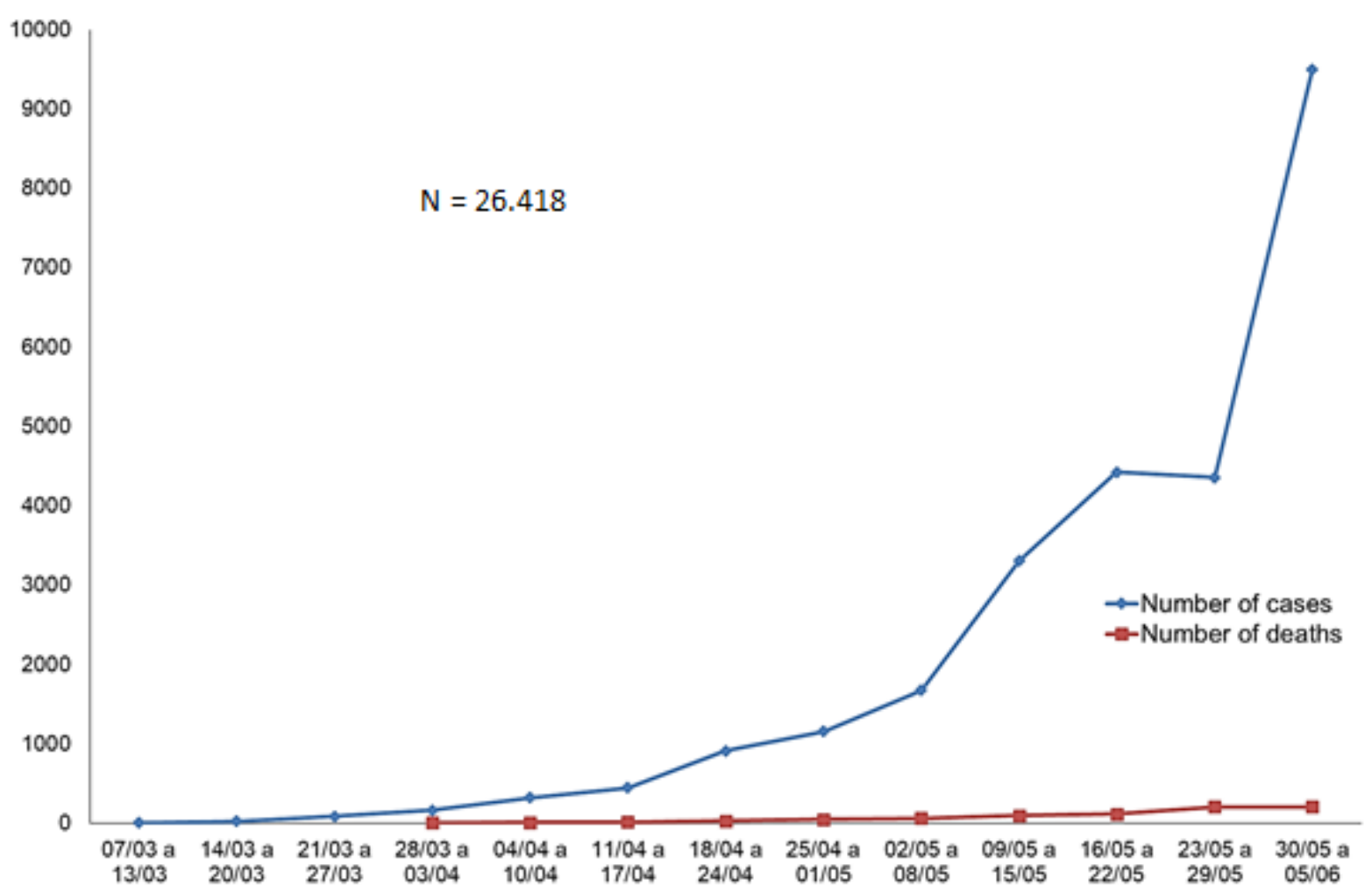

Figure 1: Number of COVID-19 cases in the State of Bahia counted according to the weeks (Source:

Research data). N - Number of cases 
A considerable increase in new cases can be seen from March 28, 2020, with an exponential increase since then, as well as the appearance of the first deaths. In addition, a doubling of confirmed cases of covid-19 was observed between $05 / 23$ to 05/29 and 05/30 to 06/05, going from 4360 new cases to 9502 , respectively, without changes in the number of deaths.

Another duplication of new cases occurred between $5 / 2$ to $8 / 8$ and $9 / 9$ to $5 / 15$ of 2020 , going from 1,678 new cases to 3,310 respectively. However, in these evaluated weeks, there was an increase in deaths, going from 66 to 68 in this short period of time. On the other hand, there was no increase between the weeks of $05 / 23$ to $05 / 29$ and from $05 / 30$ to $05 / 06$.

In a study carried out in Rio de Janeiro between March 6, 2020 and April 10, 2020, 1808 cases of covid-19 were observed, with 92 deaths, and an incidence rate of 26.8/100 thousand inhabitants. In addition, there was a considerable increase in new cases from $03 / 23$, and a doubling of new cases from 07/04, going from 49 cases to approximately 100 (Cavalcante \& Abreu, 2020).

The most affected sex was male (55\%). The most affected age group was 60 years old or more $(51 \%)$, followed by 50 to 59 years old (16\%) and 40 to 49 years old (16\%), 30 to 39 years old (10\%), 20 to 29 years old (4\%), <2 years (1.3\%), 10 to 19 years (1\%), 2 to 4 years $(0.3 \%)$ and 5 to 9 years $(0.2 \%)$. It is possible to observe an association between sex and age in Table 1.

Table 1. Association between sex and age group of individuals affected by individuals affected by Severe Acute Respiratory Syndrome (SARS) caused by the coronavirus sars in the State of Bahia, between March 7 to June 5, 2020.

\begin{tabular}{|c|c|c|c|c|c|}
\hline \multirow[t]{2}{*}{ Age range } & \multicolumn{2}{|c|}{ Male } & \multicolumn{2}{|c|}{ Women } & \multirow[t]{2}{*}{$P$} \\
\hline & $\mathbf{N}$ & $\%$ & $\mathbf{N}$ & $\%$ & \\
\hline 0 to 19 years & 26 & 2.4 & 30 & 3.4 & \\
\hline 20 to 59 years & 510 & 47.0 & 404 & 45.3 & 0.372 \\
\hline From 60 years & 549 & 50.6 & 458 & 51.3 & \\
\hline Total & 1,085 & 100 & 892 & 100 & \\
\hline
\end{tabular}

Analyzing table 1 , it is possible to observe that male individuals were the most affected (54.9\%) with coronavirus SARS, compared to the female group (45.1\%). It is noteworthy that the age that most prevailed among the cases was from 60 years old, with a contingent of $50.9 \%$, however there was no statistically significant association between the variables $(p=0.372)$.

The higher prevalence of male individuals may be associated with the fact that men produce less type I interferon (IFN), inflammatory cytokines and circulating $T$ cells compared to women, causing these individuals to have less defense against viroses (Brandão et al., 2020).

Regarding the age group, it is seen worldwide that the most affected by the syndrome are individuals over 60 years old, similar to the data found in the present research. With senescence, 
the appearance of chronic non-communicable diseases such as hypertension, diabetes, heart disease and respiratory diseases are common, making the elderly a risk group for Covid-19 and its possible complications, such as SARS (Bastos et al., 2020). Adding to that, the alterations in the metabolism of elderly people makes this group more susceptible, due to the dysregulation of the immune response, decrease in the production of sex hormones and considerable imbalance in the coagulation /fibrinolytic system and endothelial dysfunction (Silva et al., 2020).

Table 2 shows the lethality rate of Severe Acute Respiratory Syndrome caused by SARSCoV-2, according to sex and age group.

Table 2. Lethality rate by sex and age group, of Severe Acute Respiratory Syndrome (SARS) caused by SARS-Cov-2 in the State of Bahia, between March 7 to June 5, 2020.

\begin{tabular}{ccccccc}
\hline Age range & \multicolumn{3}{c}{ Male } & \multicolumn{3}{c}{ Women } \\
\hline & Cases & Deaths & LR(\%) & Cases & Deaths & LR(\%) \\
\hline$<2$ years & 13 & 01 & 7.7 & 13 & 02 & 15.4 \\
2 to 4 years & 03 & 02 & 66.7 & 00 & 00 & 0.0 \\
5 to 9 years & 00 & 00 & 0.0 & 00 & 00 & 0.0 \\
10 to 19 years & 00 & 00 & 0.0 & 00 & 00 & 0.0 \\
20 to 29 years & 33 & 09 & 27.3 & 46 & 04 & 8.7 \\
30 to 39 years & 104 & 21 & 20.2 & 95 & 12 & 12.6 \\
40 to 49 years & 185 & 44 & 23.8 & 131 & 33 & 25.2 \\
50 to 59 years & 188 & 78 & 41.5 & 132 & 43 & 32.6 \\
From 60 years & 549 & 302 & 55.0 & 458 & 255 & 55.7 \\
\hline Total & 1,085 & 457 & 42.1 & 892 & 349 & 39.1 \\
\hline \multicolumn{7}{c}{ LR - lethality rate. } \\
\end{tabular}

In general, of the 806 deaths, there was a higher lethality in males (42.1\%) compared to females (39.1\%). It is also verified that, in both sexes, there is a progressive increase in the lethality rate based on the age group of 20 to 29 years old and the subsequent age groups. In addition, it is noted that the disease was more lethal in women aged 60 and over (55.7\%), while among men the lethality was higher among those aged 2 to 4 years (66.7\%). However, in this last data it is important to point out that the high lethality in this age group is directly related to the small number of cases, so that the group's representativeness for this result can be compromised.

Some prognostic factors may be associated with increases in the mortality rate due to COVID-19 and its complications such as SARS, such as male sex, age greater than or equal to 60 years, comorbidities, among others (XIE; CHEN, 2020). Apparently, age is the most important factor for the prognosis (Yi et al., 2020).

Older people are mostly affected by comorbidities, which is why SARS-CoV-2 infection may be more severe in this group (Shahid et al., 2020). In this sense, data from the state of Bahia present in the "Sistema de Informações sobre Mortalidade" (SIM) indicate that, in 2018, 9,569 deaths from hypertensive diseases, diabetes mellitus and asthma were registered, in which $82.9 \%$ occurred in people aged 60 years or older, which shows the impact of chronic non-communicable diseases on the elderly (BRASIL, 2018). 
Table 3 shows the association between sex, age group, as well as deaths and their absence, of individuals who developed SARS, caused by SARS-Cov- 2 in the State of Bahia.

Table 3. Association between sex, age group and death and absence of death, of individuals affected by Severe Acute Respiratory Syndrome (SARS) caused by the coronavirus sars in the State of Bahia, from March 7 to June 5 , 2020.

\begin{tabular}{cccccc}
\hline & \multicolumn{2}{c}{ Death } & \multicolumn{2}{c}{ Absence of death } & P \\
& $\mathrm{N}$ & $\%$ & $\mathrm{~N}$ & $\%$ & \\
\hline Male & 457 & 56.7 & 628 & 53.6 & \\
Women & 349 & 43.3 & 543 & 46.4 & 0.178 \\
\hline Total & 806 & 100 & 1,171 & 100 & \\
\hline 0 to 19 years & 05 & 0.6 & $51+$ & 4.4 & \\
20 to 59 years & 244 & 30.3 & $670+$ & 57.2 & $<0.001$ \\
From 60 years & $557+$ & 69.1 & 450 & 38.4 & \\
\hline Total & 806 & 100 & 1,171 & 100 & \\
\hline
\end{tabular}

p - Chi-square test of independence; + Adjusted waste> 1.96 .

$\mathbf{N}$ - Number of cases.

Source: Research data.

Regarding the number of deaths of those affected, higher mortality was observed in males, with $56.7 \%$, however there was no statistical association between the variables $(p=0.178)$. Death cases related to the age group were most commonly observed among individuals aged 60 years and over and uncommon in individuals aged 0 to 19 years, for both sexes. In addition, there was a positive association for death in individuals aged 60 years or older and a positive association for absence of death between individuals aged 0 to 19 years and 20 to 59 years $(p<0.001)$.

In a study carried out in Maranhão, from February 28 to March 19, 2020, of 100 people who died from COVID-19, 62\% were male and with respect to age group, $66 \%$ of cases were people with 60 years or more (Almeida et al., 2020).

Goh et al. (2020) also discussed the relationship between age group and deaths from COVID-19. When analyzing data from 50 countries, in which the total number of cases was $2,017,444$ and that of deaths 137,166 , the authors reported a significant association ( $p=0.04)$ between the proportion of people aged 65 and over and the lethality rate. On the other hand, there was no significant association between the lethality rate and the male gender $(p=0.26)$.

According to Silva et al. (2020) it is not possible to clarify precisely the reasons responsible for the higher male mortality in individuals who presented SARS to the detriment of COVID-19. However, it is seen that women seem to have greater defense against infectious diseases, as they have duplicated $X$ chromosome (which holds most of the immunity-related genes).

Regarding the age group, the higher mortality observed in the elderly may be related not only to immunosenescence, but also to the capacity that these individuals have to produce higher concentrations of pro-inflammatory mediators such as interleukin 6 (IL-6). This, in turn, is involved with inflammation and persistent lesion of the lung parenchyma, and promotion of viral replication, which causes a worsening of the clinical picture and poor prognosis in patients over 60 years old (Bonafè et al., 2020; Pacheco, Silva \& Soares, 2020). 


\section{CONCLUSION}

From what was exposed, it appears that there was an accelerated growth in the number of people affected by COVID-19 in Bahia during the three months analyzed. With regard to individuals with the disease who developed severe acute respiratory syndrome, it was observed that those belonging to the male sex and over 60 years old had higher records of cases and deaths, as well as a higher lethality rate.

In the statistical analysis, there was a positive association between the outcome "death" and individuals aged 60 or over, while there was no significant difference between the sex of the affected and the clinical outcome.

Thus, the importance of the results described here is emphasized, given that there is a lack of studies that address epidemiological aspects of severe acute respiratory syndrome, one of the complications associated with COVID-19. Such information can assist in the development of new research, as well as guide the actions to be taken to treat SARS.

\section{REFERENCES}

Almeida, J. S., Cardoso, J. A., Cordeiro, E. C., Lemos, M., Araújo, T. M. E., Sardinha, A. H. L. (2020). Caracterização Epidemiológica dos casos de COVID-19 no Maranhão: Uma Breve Análise. Revista Prevenção de Infecção Saúde, 6, 1-14.

Al-qahtani, A. A. (2020). Severe Acute Respiratory Syndrome Coronavirus 2 (SARS-CoV-2): Emergence, history, basic and clinical aspects. Saudi Journal of Biological Sciences, 27(2), 1-8.

Bastos, L. S., Niquini, R. P., Lana, R. M., Villela, D. A. M., Cruz, O. G., Coelho, F. C., Codeço, C. T., Gomes, M. F. C. (2020). COVID-19 e hospitalização por SRAG no Brasil: uma comparação até a 12ª̀semana epidemiológica de 2020. Cadernos de Saúde Pública (online), 36(4), 1-8.

Bonafè, M., Prattichizzob, F., Giulianic, A., Storcia, G., Sabbatinellic, J., Olivieric, F. (2020). Inflammaging: Why older men are the most susceptible to SARS-CoV-2 complicated outcomes. Cytokine \& Growth Factor Reviews, 53, 33-37.

Brandão, S. C. S., Silva, E. T. A. G. B. B., Ramos, J. O. X., Melo, L. M. M. P., Sarinho, E. S. C. (2020). COVID-19, Imunidade, Endotélio e Coagulação: Compreenda a Interação. Mariola Comunicação-Recife: UFPE, 20-35.

BRASIL. (2018). Ministério da Saúde. Departamento de informática do Sistema Único de SaúdeDATASUS. Sistema de Informações sobre Mortalidade - SIM. Bahia. Óbitos por residência.

Cavalcante, J. R., Abreu, A. J. L. (2020). COVID-19 no município do Rio de Janeiro: análise espacial da ocorrência dos primeiros casos e óbitos confirmados. Epidemiol. Serv. Saude, 29(3), 1-10. 
Chen, N., Zhou, M., Dong, X., Qu, J., Gong, F., Han, Y., Qiu, Y., Wang, J., Liu, Y., Wei, Y., Xia, J., Yu, T., Zhang, X. \& Zhang, L. (2020). Epidemiological and clinical characteristics of 99 cases of 2019 novel coronavirus pneumonia in Wuhan, China: a descriptive study. The Lancent, 395, 507513.

Cheng, Z. J., Shan, J. (2020). 2019 Novel coronavirus: where we are and what we know. Infection, 48(2), 155-163.

Clausen, T. M., Sandoval, D. R., Spliid, C. B., Pihl, J., Perrett, H. R., Painter, C. D., Narayanan, A., Sydney, E. A., Kowng, M., McVicar, R. N., Thacker, B. E., Glass, C. A., Yang, Z., Torres, J. L., Golden, G. J., Bartels, P. L., Porell, R. N., Garretson, A. F. et al. (2020). SARS-CoV-2 Infection Depends on Cellular Heparan Sulfate and ACE2. CellPress, 183(12), 1-15.

Costa, V. G., Moreli, M. L., Saivish, M. V. (2020). The emergence of SARS, MERS and novel SARS-2 coronaviruses in the 21st century. Archives of Virology, 165(7), 1517-1526.

Domingo, P., Mur, I., Pomar, V., Corominas, H., Casademont, J., Benito, N. (2020). The four horsemen of a viral Apocalypse: The pathogenesis of SARS-CoV-2 infection (COVID-19). EBioMedicine, 58, 1-12.

Fundação Oswaldo Cruz (FIOCRUZ). (2020). Monitora COVID-19. 2020

Goh, H. P., Mahari, W. I., Ahad, N. I., Chaw, L. L., Kifli, N., Goh, B. H., Yeoh, S. F., Ming, L. C. (2020). Risk factors affecting COVID-19 case fatality rate: A quantitative analysis of top 50 affected countries. MedRxiv, 1-14.

Hui, D. S. C., Zumla, A. (2019). Severe Acute Respiratory Syndrome: Historical, Epidemiologic, and Clinical Features. Infectious Disease Clinics of North America, 33(4), 869-889.

Instituto Brasileiro de Geografia e Estatística (IBGE). (2019). Estado da Bahia.

Lima, C. M. A. O. (2020). Informações sobre o novo coronavírus (COVID-19). Radiologia Brasileira, $53(2), 5-6$.

Pacheco, E. S., Silva, V. R., Soares, L. S. (2020). A Brief Epidemiological Analysis of Covid-19 in Piauí, BRAZIL. Revista Prevenção de Infecção e Saúde, 6, 1-15.

Pan American Health Organization (PAHO). (2020). Folha informativa - COVID-19 (doença causada pelo novo coronavírus).

Santos, S. C., Filho, L. C. M. L., Santos, T. A. M., Santos, T. A. C., Neil, S. J., Vale, F. H., Kurnutala, N. L. (2020). Assistência perioperatória de paciente com infecção pelo SARS-CoV-2 (COVID-19) submetido a ressecção de tumor de hipófise urgente. Relato de caso e diretrizes para manejo de via aérea. Rev Bras Anestesiol, 1-6.

Shahid, Z., Kalayanamitra, R., Mcclafferty, B., Kepko, D., Ramgobin, D., Patel, R., Aggarwal, C. S., Vunnam, R., Sahu, N., Bhatt, D., Jones, K., Golimari, R., Jain, R. (2020). COVID-19 and Older Adults: What We Know. Journal of the American Geriatrics Society, 68(5), 926-929. 
Silva, A. W. C., Cunha, A. A., Alves, G. C., Corona, R. A., Dias, C. A. G. M., Nassiri, R., Vedovelli, S., Araújo, M. H. M., Souza, K. O., Oliveira, E., Dendasck, C. V., Fecury, A. A. (2020). Caracterização clínica e epidemiologia de 1560 casos de COVID-19 em Macapá/AP. Researct, Society and Development, 9(8), 1-21.

Silva, J. P. B., Costa, L. N., Monteiro, T. A. S., Pinto, T. O., Portela, N. C. (2020). Epidemiological analysis of confirmed COVID-19 cases in Caxias, Maranhão, Brazil. Revista Prevenção de Infecção e Saúde, 6(1), 1-10.

Silveira, B. M., Oliveira, L. D., Silva, M. N., Fonotti, A., Pereira, G. L., Manrique, C. J. L. (2020). Perfil dos casos de Síndrome Respiratória Aguda Grave obtidos por um laboratório de referência em Saúde Pública. Revista Eletrônica da FAINOR, Vitória da Conquista, 13(2), 310-322.

Trindade, G. G., Caxito, S. M. C., Xavier, A. R. E. O., Xavier, M. A. S., Brandão, F. (2020). COVID-19: therapeutic approaches description and discussion. An Acad Bras Cienc, 92(2), 1-15.

Yi, Y., Lagniton, P. N. P., Ye, S., Li, E., Xu, R.H. (2020). COVID-19: what has been learned and to be learned about the novel coronavirus disease. International Journal of Biological Sciences, 16(10), 1753-1766.

\section{COMO CITAR ESTE ARTIGO:}

Ferreira, D. A., Silva, W. B. da, Silva, A. P. da, Eloy, M. A., Cordeiro, L. V., Andrade Jr, F. P. de (2020). Epidemiology of severe acute respiratory syndrome (SARS) caused by covid-19 in the state of bahia. Holos, 36(5), 1-11.

\section{SOBRE OS AUTORES}

\section{A. FERREIRA}

Graduando em Farmácia pela Universidade Federal de Campina Grande, Centro de Educação e Saúde, Campus Cuité-PB. E-mail: daviazevedoferreira@hotmail.com

ORCID ID: https://orcid.org/0000-0002-5262-6262

\section{W. B. DA SILVA}

Graduando em Farmácia pela Universidade Federal de Campina Grande, Centro de Educação e Saúde, Campus Cuité-PB. E-mail: bernardodswagner@gmail.com

ORCID ID: https://orcid.org/0000-0003-0544-2193

\section{A. P. DA SILVA}

Graduando em Farmácia pela Universidade Federal de Campina Grande, Centro de Educação e Saúde, Campus Cuité-PB. E-mail: alisonpds2@gmail.com

ORCID ID: https://orcid.org/0000-0002-9662-4111

\section{A. ELOY}

Graduando em Farmácia pela Universidade Federal de Campina Grande, Centro de Educação e Saúde, Campus Cuité-PB. E-mail: mateusaraujoeloy@gmail.com

ORCID ID: https://orcid.org/0000-0001-8102-3594

\section{V. CORDEIRO}

Doutoranda em Produtos Naturais e Sintéticos Bioativos, Centro de Ciências da Saúde, Departamento de 
Ciências Farmacêuticas. Universidade Federal da Paraíba - UFPB. João Pessoa - PB. E-mail: laisavilar@gmail.com

ORCID ID: https://orcid.org/0000-0002-8884-7331

\section{F. P. DE ANDRADE JR}

Doutorando em Produtos Naturais e Sintéticos Bioativos, Centro de Ciências da Saúde, Departamento de Ciências Farmacêuticas. Universidade Federal da Paraíba - UFPB. João Pessoa - PB. E-mail: juniorfarmacia.ufcg@outlook.com

ORCID ID: https://orcid.org/0000-0003-0681-8439

Editor(a) Responsável: Francinaide de Lima Silva Nascimento Pareceristas Ad Hoc: HUGO ROCHA E KALYANE KELLY DUARTE DE OLIVEIRA

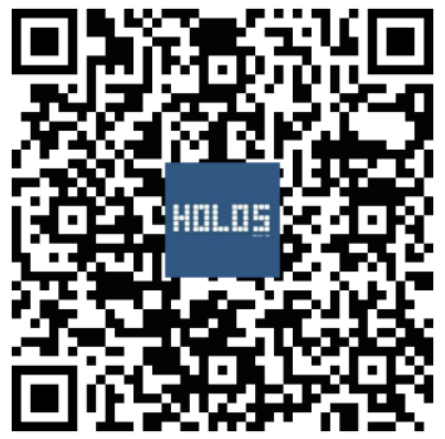

